\title{
Quality of Life after Autologous Peripheral Blood Stem Cell Transplantation and High-Dose Chemotherapy in High-Risk Breast Cancer Patients
}

\author{
Li Zhang ${ }^{a, c}$ Zhongsheng Tong ${ }^{a, c}$ Shufen $\mathrm{Li}^{\mathrm{a}, \mathrm{c}}$ Xiubao Ren ${ }^{\mathrm{b}, \mathrm{d}}$ Baozhu Ren ${ }^{\mathrm{b}, \mathrm{d}}$ Xu Wang ${ }^{\mathrm{a}, \mathrm{c}}$ \\ Shui $\mathrm{CaO}^{\mathrm{b}, \mathrm{d}}$ Chen Wang ${ }^{\mathrm{a}, \mathrm{c}}$ Lihong He
}

${ }^{a}$ Medical Department of Breast Oncology, Tianjin Medical University Cancer Institute and Hospital,

${ }^{\mathrm{b}}$ Department of Biotherapy, Tianjin Medical University Cancer Institute and Hospital,

${ }^{c}$ Key Laboratory of Breast Cancer Prevention and Therapy, Ministry of Education,

${ }^{\mathrm{d}}$ Key Laboratory of Cancer Prevention and Therapy, Tianjin, China

\section{Key Words}

Quality of life - Autologous peripheral blood stem cell transplantation · High-risk breast cancer

\section{Summary}

Background: As long-term survivors of breast cancer after autologous peripheral blood stem cell transplantation (ASCT) are becoming more numerous, studies addressing the issue of long-term follow-up are necessary. In this study, we report on the quality of life (QOL) after ASCT and high-dose chemotherapy (HDCT). Patients and Methods: The QOL questionnaire version 3.0 by the European Organization for Research and Treatment of Cancer (EORTC QLQ-C30 version 3.0) was filled in by patients and healthy controls at 5 time points. After obtaining the results, we analyzed the correlation between QOL and the effect factors. Results: Some functions got significantly worse, and some symptoms got more serious after ASCT and HDCT. However, most of them improved with time and were comparable to the healthy controls after 5 years. QOL was in part related to age, tumor characteristics, educational level, marriage status, and income. Conclusions: Evaluating QOL allows medical workers to fully understand a patient's state of health, and aid the estimation and selection of clinical treatment methods as well as improve recovery.
Schlüsselwörter

Lebensqualität · Autologe periphere Stammzell-

transplantation · Hochrisiko-Mammakarzinom

\section{Zusammenfassung}

Hintergrund: Die steigende Anzahl langzeitüberlebender Brustkrebspatienten nach autologer peripherer Stammzelltransplantation (autologous peripheral blood stem cell transplantation, ASCT) macht Studien zum LangzeitFollow-up notwendig. Die vorliegende Studie befasst sich mit der Lebensqualität nach ASCT und HochdosisChemotherapie (HDCT). Patienten und Methoden: Der Lebensqualitätsfragebogen Version 3.0 der European Organization for Research and Treatment of Cancer (EORTC QLQ-C30, Version 3.0) wurde von sowohl Patienten als auch gesunden Kontrollpersonen zu 5 verschiedenen Zeitpunkten ausgefüllt. Anhand der Daten wurde die Korrelation zwischen Lebensqualität und Einflussfaktoren analysiert. Ergebnisse: Bei einigen Funktionen war eine signifikante Verschlechterung zu beobachten, und bestimmte Symptome verschlimmerten sich nach ASCT und HDCT. Die meisten besserten sich jedoch im Laufe der Zeit und entsprachen nach 5 Jahren dem Status der gesunden Kontrollpersonen. Die Lebensqualität war zum Teil mit Alter, Tumoreigenschaften, Bildungsstand, Ehestand und Einkommen korreliert. Schlussfolgerungen: Die Bestimmung der Lebensqualität macht es dem medizinischen Personal möglich, den Gesundheitszustand eines Patienten ganzheitlich zu erfassen, wodurch die Einschätzung und Auswahl klinischer Behandlungmethoden unterstützt und die Genesung verbessert wird.

\begin{tabular}{ll}
\hline KARGER & ๑ 2009 S. Karger GmbH, Freiburg \\
Fax +497614520714 & Accessible online at: \\
Information@Karger.de & www.karger.com/brc \\
www.karger.com &
\end{tabular}

Zhongsheng Tong, MD

Medical Department of Breast Oncology, Tianjin Medical University Cancer Institute and Hospital

Tiyuan North, Hexi District, Tianjin 300060, China

Tel. +86 22 233-40123, Fax -511809

tonghang@medmail.com.cn 


\section{Introduction}

Breast cancer remains one of the most common malignancies affecting women's health. Primary breast cancer patients with metastases in $>10$ axillary lymph nodes, or in $>4$ axillary lymph nodes and negative estrogen status, or with locally advanced disease (high-risk breast cancer patients) always have a worse prognosis after conventional chemotherapy. Highdose chemotherapy (HDCT) followed by autologous peripheral stem cell transplantation (ASCT) is increasingly being used in malignant lymphoma, Hodgkin's disease, high-risk breast cancer, and so on [1,2]. As experience with ASCT has become more widespread and the number of patients who have survived for longer periods after the procedure has increased, health-related quality of life (QOL) after treatment is receiving increased attention [3,4]. In recent years, some studies examined the impact of HSCT on the QOL. Highdose treatment and HSCT are associated with high physical and emotional distress levels and reduced QOL [5, 6]. However, there are several studies about bone marrow transplantation but very few about HDCT followed by ASCT [7, 8]. Also, data published thus far are limited by short follow-up [9-11]. The objectives of this study are: i) to examine the effects of ASCT on QOL; ii) to determine the relationship between long-term QOL and the interval from transplantation; iii) to analyze the correlation between QOL and effect factors (age, tumor characteristics, educational level, marriage, income); iv) to discuss how the QOL of cancer patients may be improved [12-14].

The European Organization for Research and Treatment of Cancer (EORTC) quality of life questionnaire (QLQ-C30) was translated into many languages and used in various countries to evaluate QOL of cancer patients. As a core measure, it can be used to evaluate lymphoma, lung cancer, breast cancer, and so on. In this study, we chose EORTC QLQ-C30 version 3.0 as a study instrument [15].

\section{Patients and Methods}

\section{Patients}

The study population consisted of 61 patients who had received a histopathologically confirmed diagnosis of high-risk breast cancer between October 1999 and June 2004, and to whom the following applied: i) histopathologically confirmed diagnosis of primary breast cancer following radical surgery; number of positive axillary lymph nodes $>4$ and estrogen receptor-negative, or number of positive axillary lymph nodes $>10$ with no distant metastasis; ii) indication for treatment with ASCT and HDCT; iii) basic perceptivity and ability to communicate. 50 healthy persons were randomly chosen as controls.

\section{Instrument and Data Collection}

EORTC QLQ-C30 version 3.0 (table 1) and a scoring manual were used to determine QOL. EORTC QLQ-30 is a 30-item questionnaire for assessing the QOL of cancer patients. It consists of 5 functioning scales (physical, role, emotional, cognitive, social), a global health and QOL scale, 3 symptom scales (fatigue, nausea/vomiting, pain), and 6 simple
Table 1. EORTC QLQ-C30 raw scores (RS) calculation

\begin{tabular}{llll}
\hline Scale & Items, $\mathrm{n}$ & Range & RS calculation \\
\hline Function scales & & & \\
$\quad$ Physical function & 5 & 3 & $(1+2+3+4+5) / 5$ \\
$\quad$ Role function & 2 & 3 & $(6+7) / 2$ \\
$\quad$ Emotional function & 4 & 3 & $(21+22+23+24) / 4$ \\
Cognitive function & 2 & 3 & $(20+25) / 2$ \\
Social function & 2 & 3 & $(26+27) / 2$ \\
Global health/QOL scale & 2 & 6 & $(29+30) / 2$ \\
Symptom scales & & & \\
$\quad$ Fatigue & 3 & 3 & $(10+12+18) / 3$ \\
Nausea/vomiting & 2 & 3 & $(14+15) / 2$ \\
Pain & 2 & 3 & $(9+19) / 2$ \\
Six simple items & & & \\
Dyspnea & 1 & 3 & 8 \\
Sleep disturbance & 1 & 3 & 11 \\
Loss of appetite & 1 & 3 & 13 \\
Constipation & 1 & 3 & 16 \\
Diarrhea & 1 & 3 & 17 \\
Financial impact & 1 & 3 & 18 \\
\hline
\end{tabular}

$\mathrm{QOL}=$ Quality of life.

items (dyspnea, sleep disturbance, loss of appetite, constipation, diarrhea, financial impact). The scoring process includes calculating raw scores (RS), converting to normal scores, dealing with missing items, and explaining the results [16]. First, we obtained the RS according to each item and the patients' options: $\mathrm{RS}=(\mathrm{I} 1+\mathrm{I} 2+\mathrm{I} 3+\ldots+\mathrm{In}) / \mathrm{n}$. Then, we linearly transformed them in such a way that all scales range from 0 to 100 : functioning scales score $=\{1-(\mathrm{RS}-1) /$ range $\} \times 100$, global health and QOL scale, symptom scales, and 6 simple items score $=\{(\mathrm{RS}-1) /$ range $\} \times 100$. Therefore, a high score on the functional scale represents a high level of functioning, but a high score for a symptom scale and single item represents a high level of symptomatology problems. A global health and QOL scale can be used as an overall measurement.

\section{Methods and Procedures}

The procedure of HDCT followed by ASCT to cure high-risk breast cancer involved the following: autologous peripheral stem cell mobilization using CAF (cytoxan + epirubicin + fluorouracil) with granulocyte colony-stimulating factor (G-CSF) $5 \mu \mathrm{g} / \mathrm{kg}+$ granulocyte macrophage colony-stimulating factor (GM-CSF) $5 \mu \mathrm{g} / \mathrm{kg}$; HDCT pretreatment with cytoxan $60 \mathrm{mg} / \mathrm{kg}$ days 1 and 2 + etoposide $350 \mathrm{mg} / \mathrm{m}^{2}$ days $1-3$ + carboplatin $1,000 \mathrm{mg} / \mathrm{m}^{2}$ day 1 ; stem cell are transfused back $2 \mathrm{~h}$ after pretreatment.

Patients filled in the EORTC QLQ-C30 at 5 time points: 1 month before transplantation (T1), 3 months after transplantation (T2), 1 year after transplantation (T3), 3 years after transplantation (T4), and 5 years after transplantation (T5). Generally, patients filled in the questionnaire by themselves. Patients who could not read, had lost their glasses, had a disability involving the fingers, or were physically weak, could be assisted by the doctors when completing the questionnaire but doctors could not make any suggestions. Patients who were unable to come to hospital to fill in the questionnaire (living far away from the hospital, being physically weak, or other reasons), completed it over the telephone.

Fifty persons (35-65 years old) were randomly chosen as healthy controls to fill in the EORTC QLQ-C30; this procedure was completed on average 5 years after transplantation (2006) in order to reduce the error caused by social status. 
Data Analysis

SPSS13.0 was used for data analysis. Differences between groups were tested with ANOVA and t-test. Correlation was analyzed by Spearman correlation analysis. Statistical significance was considered at $\mathrm{p}<0.05$.

\section{Results}

\section{Patient Information}

Patient and healthy control characteristics were collected and recorded (table 2). Some of the 61 patients did not finish the questionnaire because of death, relapse, or because they were lost to follow-up. The number of patients at the 5 time points were as follows: $\mathrm{T} 1=61(100 \%), \mathrm{T} 2=61(100 \%), \mathrm{T} 3=57$ $(93.4 \%), \mathrm{T} 4=48(78.7 \%), \mathrm{T} 5=42(68.9 \%)$.

Table 2. Characteristics of patients and healthy controls

\begin{tabular}{|c|c|c|c|c|}
\hline \multirow[t]{2}{*}{ Items } & \multicolumn{2}{|c|}{ Patients } & \multicolumn{2}{|c|}{ Controls } \\
\hline & $\mathrm{n}$ & $\begin{array}{l}\text { constituent } \\
\text { ratio, } \%\end{array}$ & $\mathrm{n}$ & $\begin{array}{l}\text { constituent } \\
\text { ratio, } \%\end{array}$ \\
\hline \multicolumn{5}{|l|}{ Age, years } \\
\hline$<40$ & 14 & 23.0 & 12 & 24.0 \\
\hline $40-55$ & 30 & 49.2 & 26 & 52.0 \\
\hline$>55$ & 17 & 27.9 & 12 & 24.0 \\
\hline \multicolumn{5}{|l|}{ Menopausal status } \\
\hline Premenopausal & 37 & 60.7 & 31 & 62.0 \\
\hline Postmenopausal & 24 & 39.3 & 19 & 38.0 \\
\hline \multicolumn{5}{|l|}{ Tumor type } \\
\hline Invasive ductal & 24 & 39.3 & & \\
\hline Medullary & 13 & 21.3 & & \\
\hline Simplex & 12 & 19.7 & & \\
\hline Other & 12 & 19.7 & & \\
\hline \multicolumn{5}{|l|}{ Tumor size } \\
\hline$<2 \mathrm{~cm}$ & 23 & 37.7 & & \\
\hline $2-5 \mathrm{~cm}$ & 25 & 41.0 & & \\
\hline$>5 \mathrm{~cm}$ & 13 & 21.3 & & \\
\hline \multicolumn{5}{|l|}{ Stage } \\
\hline II & 30 & 49.2 & & \\
\hline III & 31 & 50.8 & & \\
\hline \multicolumn{5}{|l|}{ ECOG score } \\
\hline $0-1$ & 42 & 68.9 & 41 & 82.0 \\
\hline $2-3$ & 19 & 31.1 & 9 & 18.0 \\
\hline \multicolumn{5}{|l|}{ Education level } \\
\hline Some high school or less & 19 & 31.1 & 14 & 28.0 \\
\hline Graduated from high school & 27 & 44.3 & 23 & 46.0 \\
\hline Some college or more & 15 & 24.6 & 13 & 26.0 \\
\hline \multicolumn{5}{|l|}{ Social status } \\
\hline Single/divorced/widowed & 19 & 31.1 & 35 & 70.0 \\
\hline Married/living together & 42 & 68.9 & 15 & 30.0 \\
\hline \multicolumn{5}{|l|}{ Income, RMB Yuan } \\
\hline$<2,000$ & 13 & 21.3 & 11 & 22.0 \\
\hline $2,000-4,000$ & 30 & 49.2 & 29 & 58.0 \\
\hline$>4,000$ & 18 & 29.5 & 10 & 20.0 \\
\hline
\end{tabular}

\section{Data Statistics Results}

Table 3 shows results of the statistical analysis of the patient and control data. We compared T1 to T2, T2 to T3, T4 and T5, and T5 to the controls. Figure 1 depicts the scores of the functioning scales and the global health/QOL scale. Figure 2 depicts the scores of the symptom scales and the 6 single items. From the 2 figures we can directly derive the tendency of the change. Table 4 shows the correlation between QOL and some effect factors.

\section{Functioning Scales and Global Health/QOL Scale Scores}

The change tendency of the functioning scales and the global health/QOL scale scores are shown in figure 1. Mostly, scores were at their lowest at T2 (lower than T1), and with time they increased nearing the scores of the healthy controls. However, there still were differences between healthy controls and patients at T5. The results of the statistic analysis indicated the following. Physical function was not significantly different between pretransplant and posttransplant, but patients at T5 were still statistically different from controls $(p=0.000)$. Emotional function was worse after transplantation than before $(\mathrm{p}=0.000)$ but increased 3 years after transplantation $(\mathrm{p}=$

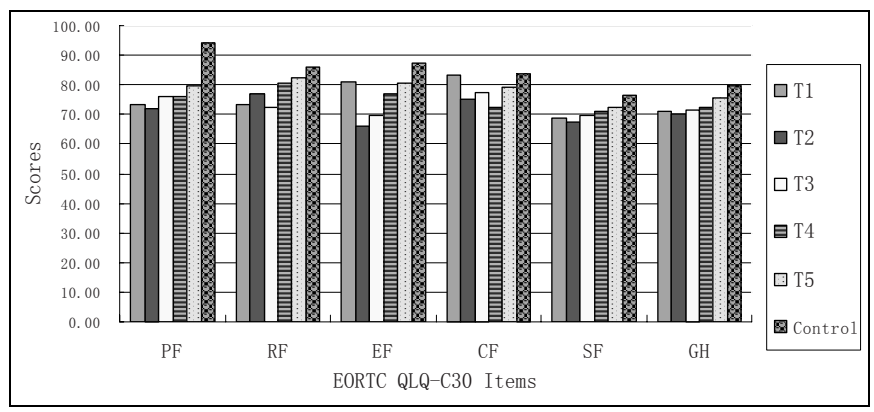

Fig. 1. Mean scores of the functioning scales and the global health/QOL scale at the 5 time points. PF: Physical function; RF: role function; EF: emotional function; CF: cognitive function; SF: social function; GH: global health.

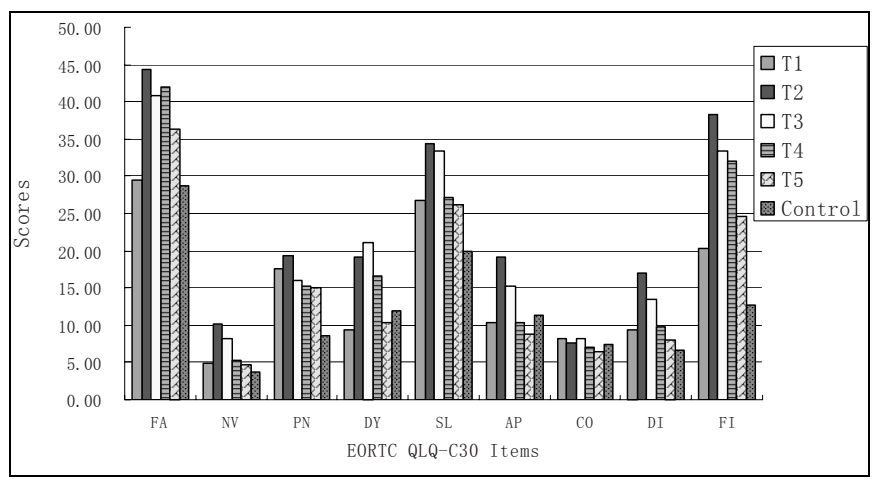

Fig. 2. Mean scores of the symptom scales and the 6 single items at the 5 time points. FA: Fatigue; NV: nausea/vomiting; PN: pain; DY: dyspnea; SL: sleep disturbance; AP: loss of appetite; CO: constipation; DI: diarrhea; FI: financial impact. 
Table 3. Mean scale and item scores of EORTC QLQ-C30 ( \pm standard deviation, SD)

\begin{tabular}{|c|c|c|c|c|c|c|}
\hline \multirow[t]{2}{*}{ Items } & \multicolumn{5}{|c|}{ Patient scores \pm SD } & \multirow{2}{*}{$\begin{array}{l}\text { Control scores } \pm \text { SD } \\
(n=50)\end{array}$} \\
\hline & $\mathrm{T} 1(\mathrm{n}=61)$ & $\mathrm{T} 2(\mathrm{n}=61)$ & $\mathrm{T} 3(\mathrm{n}=57)$ & $\mathrm{T} 4(\mathrm{n}=48)$ & T5 $(n=42)$ & \\
\hline Physical function & $73.33 \pm 14.19$ & $\begin{array}{l}72.13 \pm 12.97 \\
\mathrm{t}^{1}(0.488) \\
\mathrm{p}^{1}(0.626)\end{array}$ & $\begin{array}{l}75.91 \pm 12.39 \\
\mathrm{t}^{2}(-1.614) \\
\mathrm{p}^{2}(0.109)\end{array}$ & $\begin{array}{l}75.97 \pm 14.01 \\
\mathrm{t}^{3}(-1.482) \\
\mathrm{p}^{3}(0.141)\end{array}$ & $\begin{array}{l}79.52 \pm 12.35 \\
\mathrm{t}^{4}(-2.898) \\
\mathrm{p}^{4}(0.005)\end{array}$ & $\begin{array}{l}94.27 \pm 6.87 \\
\mathrm{t}^{5}(-7.218) \\
\mathrm{p}^{5}(0.000)\end{array}$ \\
\hline Role function & $73.22 \pm 16.18$ & $\begin{array}{l}76.78 \pm 13.70 \\
\mathrm{t}^{1}(-1.308) \\
\mathrm{p}^{1}(0.193)\end{array}$ & $\begin{array}{l}72.22 \pm 13.48 \\
\mathrm{t}^{2}(1.818) \\
\mathrm{p}^{2}(0.072)\end{array}$ & $\begin{array}{l}80.55 \pm 13.01 \\
\mathrm{t}^{3}(-1.461) \\
\mathrm{p}^{3}(0.147)\end{array}$ & $\begin{array}{l}82.14 \pm 13.96 \\
\mathrm{t}^{4}(-1.938) \\
\mathrm{p}^{4}(0.055)\end{array}$ & $\begin{array}{l}86.00 \pm 13.20 \\
\mathrm{t}^{5}(-1.359) \\
\mathrm{p}^{5}(0.177)\end{array}$ \\
\hline Emotional function & $80.19 \pm 8.54$ & $\begin{array}{l}65.98 \pm 13.63 \\
\mathrm{t}^{1}(7.184) \\
\mathrm{p}^{1}(0.000)\end{array}$ & $\begin{array}{l}69.59 \pm 12.04 \\
\mathrm{t}^{2}(-1.519) \\
\mathrm{p}^{2}(0.132)\end{array}$ & $\begin{array}{l}76.91 \pm 11.43 \\
\mathrm{t}^{3}(-4.454) \\
\mathrm{p}^{3}(0.000)\end{array}$ & $\begin{array}{l}80.36 \pm 12.18 \\
\mathrm{t}^{4}(-5.487) \\
\mathrm{p}^{4}(0.000)\end{array}$ & $\begin{array}{l}87.17 \pm 12.73 \\
\mathrm{t}^{5}(-2.606) \\
\mathrm{p}^{5}(0.011)\end{array}$ \\
\hline Cognitive function & $83.06 \pm 14.43$ & $\begin{array}{l}75.14 \pm 13.82 \\
\mathrm{t}^{1}(3.097) \\
\mathrm{p}^{1}(0.002)\end{array}$ & $\begin{array}{l}77.48 \pm 13.90 \\
\mathrm{t}^{2}(-0.920) \\
\mathrm{p}^{2}(0.360)\end{array}$ & $\begin{array}{l}72.57 \pm 14.38 \\
\mathrm{t}^{3}(-0.946) \\
\mathrm{p}^{3}(0.346)\end{array}$ & $\begin{array}{l}78.97 \pm 15.20 \\
\mathrm{t}^{4}(-1.327) \\
\mathrm{p}^{4}((0.187)\end{array}$ & $\begin{array}{l}83.67 \pm 14.08 \\
t^{5}(-1.537) \\
\mathrm{p}^{5}(0.128)\end{array}$ \\
\hline Social function & $68.58 \pm 16.13$ & $\begin{array}{l}67.49 \pm 16.51 \\
\mathrm{t}^{1}(0.370) \\
\mathrm{p}^{1}(0.712)\end{array}$ & $\begin{array}{l}69.59 \pm 12.04 \\
\mathrm{t}^{2}(-0.707) \\
\mathrm{p}^{2}(0.481)\end{array}$ & $\begin{array}{l}71.18 \pm 13.64 \\
\mathrm{t}^{3}(-1.250) \\
\mathrm{p}^{3}(0.214)\end{array}$ & $\begin{array}{l}72.22 \pm 12.57 \\
\mathrm{t}^{4}(-1.571) \\
\mathrm{p}^{4}((0.119)\end{array}$ & $\begin{array}{l}76.33 \pm 12.63 \\
\mathrm{t}^{5}(-1.558) \\
\mathrm{p}^{5}(0.123)\end{array}$ \\
\hline $\begin{array}{l}\text { Global health/QOL } \\
\text { scale }\end{array}$ & $71.04 \pm 16.00$ & $\begin{array}{l}70.22 \pm 17.31 \\
\mathrm{t}^{1}(0.272) \\
\mathrm{p}^{1}(0.786)\end{array}$ & $\begin{array}{l}71.35 \pm 14.00 \\
\mathrm{t}^{2}(-0.387) \\
\mathrm{p}^{2}(0.699)\end{array}$ & $\begin{array}{l}72.57 \pm 15.08 \\
\mathrm{t}^{3}(-0.744) \\
\mathrm{p}^{3}(0.458)\end{array}$ & $\begin{array}{l}75.40 \pm 14.13 \\
\mathrm{t}^{4}(-1.605) \\
\mathrm{p}^{4}((0.112)\end{array}$ & $\begin{array}{l}79.67 \pm 11.06 \\
\mathrm{t}^{5}(-1.625) \\
\mathrm{p}^{5}(0.108)\end{array}$ \\
\hline Fatigue & $29.51 \pm 12.97$ & $\begin{array}{l}44.26 \pm 12.91 \\
\mathrm{t}^{1}(-6.297) \\
\mathrm{p}^{1}(0.000)\end{array}$ & $\begin{array}{l}40.74 \pm 13.17 \\
\mathrm{t}^{2}(1.467) \\
\mathrm{p}^{2}(0.145)\end{array}$ & $\begin{array}{l}41.90 \pm 13.61 \\
\mathrm{t}^{3}(0.927) \\
\mathrm{p}^{3}(0.356)\end{array}$ & $\begin{array}{l}36.24 \pm 17.88 \\
\mathrm{t}^{4}(2.644) \\
\mathrm{p}^{4}(0.009)\end{array}$ & $\begin{array}{l}28.66 \pm 15.24 \\
\mathrm{t}^{5}(2.195) \\
\mathrm{p}^{5}(0.031)\end{array}$ \\
\hline Nausea/vomiting & $4.92 \pm 8.79$ & $\begin{array}{l}10.11 \pm 11.09 \\
\mathrm{t}^{1}(-2.866) \\
\mathrm{p}^{1}(0.005)\end{array}$ & $\begin{array}{l}8.18 \pm 9.51 \\
\mathrm{t}^{2}(1.007) \\
\mathrm{p}^{2}(0.316)\end{array}$ & $\begin{array}{l}5.21 \pm 7.81 \\
\mathrm{t}^{3}(2.596) \\
\mathrm{p}^{3}(0.011)\end{array}$ & $\begin{array}{l}4.76 \pm 7.62 \\
t^{4}(2.713) \\
p^{4}(0.008)\end{array}$ & $\begin{array}{l}3.67 \pm 7.00 \\
\mathrm{t}^{5}(0.719) \\
\mathrm{p}^{5}(0.474)\end{array}$ \\
\hline Pain & $17.49 \pm 17.06$ & $\begin{array}{l}19.40 \pm 17.53 \\
\mathrm{t}^{1}(-0.611) \\
\mathrm{p}^{1}(0.542)\end{array}$ & $\begin{array}{l}16.08 \pm 14.42 \\
\mathrm{t}^{2}(1.118) \\
\mathrm{p}^{2}(0.266)\end{array}$ & $\begin{array}{l}15.28 \pm 13.68 \\
\mathrm{t}^{3}(1.339) \\
\mathrm{p}^{3}(0.183)\end{array}$ & $\begin{array}{l}15.08 \pm 13.68 \\
\mathrm{t}^{4}(1.340) \\
\mathrm{p}^{4}(0.183)\end{array}$ & $\begin{array}{l}8.67 \pm 10.78 \\
\mathrm{t}^{5}(2.515) \\
\mathrm{p}^{5}(0.014)\end{array}$ \\
\hline Dyspnea & $9.29 \pm 18.39$ & $\begin{array}{l}19.12 \pm 18.72 \\
\mathrm{t}^{1}(-2.927) \\
\mathrm{p}^{1}(0.004)\end{array}$ & $\begin{array}{l}21.05 \pm 19.55 \\
\mathrm{t}^{2}(-0.547) \\
\mathrm{p}^{2}(0.585)\end{array}$ & $\begin{array}{l}16.67 \pm 19.45 \\
\mathrm{t}^{3}(2.591) \\
\mathrm{p}^{3}(0.505)\end{array}$ & $\begin{array}{l}10.32 \pm 17.25 \\
\mathrm{t}^{4}(2.422) \\
\mathrm{p}^{4}(0.017)\end{array}$ & $\begin{array}{l}12.00 \pm 16.16 \\
\mathrm{t}^{5}(-0.482) \\
\mathrm{p}^{5}(0.631)\end{array}$ \\
\hline Sleep disturbance & $26.78 \pm 30.92$ & $\begin{array}{l}34.43 \pm 29.79 \\
\mathrm{t}^{1}(-1.391) \\
\mathrm{p}^{1}(0.167)\end{array}$ & $\begin{array}{l}33.33 \pm 25.97 \\
\mathrm{t}^{2}(0.212) \\
\mathrm{p}^{2}(0.833)\end{array}$ & $\begin{array}{l}27.08 \pm 23.48 \\
\mathrm{t}^{3}(0.262) \\
\mathrm{p}^{3}(0.165)\end{array}$ & $\begin{array}{l}26.19 \pm 22.73 \\
\mathrm{t}^{4}(1.513) \\
\mathrm{p}^{4}(0.133)\end{array}$ & $\begin{array}{l}20.00 \pm 22.33 \\
\mathrm{t}^{5}(1.313) \\
\mathrm{p}^{5}(0.192)\end{array}$ \\
\hline Loss of appetite & $10.38 \pm 17.19$ & $\begin{array}{l}19.12 \pm 18.72 \\
\mathrm{t}^{1}(-2.645) \\
\mathrm{p}^{1}(0.009)\end{array}$ & $\begin{array}{l}15.20 \pm 17.89 \\
\mathrm{t}^{2}(1.161) \\
\mathrm{p}^{2}(0.248)\end{array}$ & $\begin{array}{l}10.41 \pm 15.61 \\
\mathrm{t}^{3}(1.904) \\
\mathrm{p}^{3}(0.011)\end{array}$ & $\begin{array}{l}8.73 \pm 14.83 \\
\mathrm{t}^{4}(3.006) \\
\mathrm{p}^{4}(0.003)\end{array}$ & $\begin{array}{l}11.33 \pm 15.95 \\
\mathrm{t}^{5}(-0.805) \\
\mathrm{p}^{5}(0.423)\end{array}$ \\
\hline Constipation & $8.20 \pm 16.84$ & $\begin{array}{l}7.65 \pm 14.13 \\
\mathrm{t}^{1}(0.194) \\
\mathrm{p}^{1}(0.846)\end{array}$ & $\begin{array}{l}8.18 \pm 14.47 \\
\mathrm{t}^{2}(-0.204) \\
\mathrm{p}^{2}(0.839)\end{array}$ & $\begin{array}{l}6.94 \pm 13.68 \\
\mathrm{t}^{3}(1.386) \\
\mathrm{p}^{3}(0.793)\end{array}$ & $\begin{array}{l}6.35 \pm 13.25 \\
\mathrm{t}^{4}(0.471) \\
\mathrm{p}^{4}(0.639)\end{array}$ & $\begin{array}{l}7.33 \pm 13.95 \\
\mathrm{t}^{5}(-0.345) \\
\mathrm{p}^{5}(0.731)\end{array}$ \\
\hline Diarrhea & $9.29 \pm 18.39$ & $\begin{array}{l}16.94 \pm 21.62 \\
\mathrm{t}^{1}(-2.105) \\
\mathrm{p}^{1}(0.037)\end{array}$ & $\begin{array}{l}13.44 \pm 18.75 \\
\mathrm{t}^{2}(0.934) \\
\mathrm{p}^{2}(0.352)\end{array}$ & $\begin{array}{l}9.72 \pm 16.78 \\
\mathrm{t}^{3}(-1.614) \\
\mathrm{p}^{3}(0.060)\end{array}$ & $\begin{array}{l}7.94 \pm 14.37 \\
\mathrm{t}^{4}(2.362) \\
\mathrm{p}^{4}(0.020)\end{array}$ & $\begin{array}{l}6.67 \pm 13.47 \\
t^{5}(0.437) \\
p^{5}(0.663)\end{array}$ \\
\hline Financial impact & $20.22 \pm 22.18$ & $\begin{array}{l}38.25 \pm 25.70 \\
\mathrm{t}^{1}(-4.149) \\
\mathrm{p}^{1}(0.000)\end{array}$ & $\begin{array}{l}33.33 \pm 22.71 \\
\mathrm{t}^{2}(1.098) \\
\mathrm{p}^{2}(0.274)\end{array}$ & $\begin{array}{l}31.94 \pm 20.58 \\
\mathrm{t}^{3}(-1.614) \\
\mathrm{p}^{3}(0.169)\end{array}$ & $\begin{array}{l}24.60 \pm 20.90 \\
\mathrm{t}^{4}(2.852) \\
\mathrm{p}^{4}(0.005)\end{array}$ & $\begin{array}{l}12.67 \pm 18.92 \\
\mathrm{t}^{5}(2.847) \\
\mathrm{p}^{5}(0.005)\end{array}$ \\
\hline
\end{tabular}

QOL $=$ Quality of life.

$\mathrm{t}^{1}=\mathrm{t}$ from the comparison of $\mathrm{T} 1$ and $\mathrm{T} 2 ; \mathrm{p}^{1}$ is the corresponding $\mathrm{p}$ value.

$\mathrm{t}^{2}=\mathrm{t}$ from the comparison of $\mathrm{T} 2$ and $\mathrm{T} 2 ; \mathrm{p}^{2}$ is the corresponding $\mathrm{p}$ value.

$\mathrm{t}^{3}=\mathrm{t}$ from the comparison of $\mathrm{T} 2$ and $\mathrm{T} 4 ; \mathrm{p}^{3}$ is the corresponding $\mathrm{p}$ value.

$\mathrm{t}^{4}=\mathrm{t}$ from the comparison of $\mathrm{T} 2$ and $\mathrm{T} 5 ; \mathrm{p}^{4}$ is the corresponding $\mathrm{p}$ value.

$\mathrm{t}^{5}=\mathrm{t}$ from the comparison of T5 and the control; $\mathrm{p}^{5}$ is the corresponding $\mathrm{p}$ value.

$\mathrm{p}<0.05$ means the difference has statistical significance. 
0.000); after 5 year a difference remained to the healthy controls $(\mathrm{p}=0.011)$. Cognitive function was impaired after transplantation $(p=0.002)$, then got gradually better and was same as healthy controls after 5 years. Role, social functions, and global health were not significantly different after transplantation.

\section{Symptom Scales and Six Single Items Scores}

Figure 2 shows the change tendency of the symptom scales and the 6 single item scores. Mostly, the scores were at their highest at T2, which means symptoms posttransplant were more serious than pretransplant, and with time they improved and neared the healthy controls. However, some problems were not resolved after T5. The results of the statistic analysis indicated that fatigue symptoms were more serious after transplant $(\mathrm{p}=0.000)$, and while significantly relieved at T5 $(\mathrm{p}=0.009)$ were still different to the healthy controls ( $\mathrm{p}=$ $0.031)$. Nausea and loss of appetite were more conspicuous at $\mathrm{T} 2(\mathrm{p}=0.005, \mathrm{p}=0.009)$, but were significantly improved after T3 $(p=0.011)$ and comparable to controls at T5. Pain was a serious problem which constantly impaired QOL and was not resolved completely even after 5 year $(p=0.014)$. Dyspnea and diarrhea were worse after transplantation $(\mathrm{p}=0.004, \mathrm{p}=0.037)$ but got better after T5 $(\mathrm{p}=0.017, \mathrm{p}=0.020)$. The financial impact was more serious post- than pretransplant $(\mathrm{p}=0.000)$, and while relieved after 5 years $(\mathrm{p}=0.005)$ was still different to healthy controls $(\mathrm{p}=0.005)$.

\section{Correlation Analysis Results}

Spearman correlation analysis was used to compare some effect factors with the QOL scores at T2 based on $r$ and $p$ values (table 4). We found age was negatively correlated with physical functions and global health, and positively correlated with fatigue and sleep disturbance. Menopausal status has positively correlated with emotional function, fatigue, and diarrhea. Tumor size, stage, and ECOG score were negatively correlated with physical function, and positively correlated with sleep disturbance. Education level was negatively correlated with emotional function. Social status was positively correlated with emotional functions and global health, but negatively correlated with constipation. Income was positively correlated with physical function, but negatively correlated with cognitive function and financial impact.

\section{Discussion}

\section{Function and Global Health}

An international multicenter and multiscale study [17] indicated that patients' QOL was still worse than that of healthy controls 7 years after transplant, which usually involved symptoms such as sleep disturbance, physical fitness descent, fatigue, and pain. Other studies [18] showed that most pa- tients felt satisfied with their QOL 1 year after transplant, and $55 \%$ of patients employed prior to treatment returned full-time or part-time to their previous occupation. Even if QOL was not very good 1 year on, it would be better after 2-5 years.

From this study, we conclude that ASCT and HDCT have a significant impact on several QOL issues. Mostly, the scores were the lowest just after the transplant, and with time improved and neared the healthy controls. However, QOL was still different between patients and healthy controls at T5. Physical function reflects the status of daily activities which existed before and after ASCT and HDCT in the lives of highrisk breast cancer patients, and impairment of physical function was hard to resolve even after 5 years. Cancer patients have to accept the pain of disease, chemotherapy, transplantation, and treatment, leading to reduced physical capacity and fatigue. Some patients were worried about the disease being advanced and lost confidence to do certain daily activities. Doctors and families should encourage patients to be self-confident and exercise in order to recover physical function.

Hjermstad et al. [19] conducted a study on QOL after transplantation that included a 1-year follow-up. In their report, they concluded that allotransplant patients had higher functional scores and less symptomatology than autologous transplant patients or the control chemotherapy patients. The patients' emotional function was somewhat impacted by transplantation, especially in the form of anxiety and depression, with some patients requiring psychotropic drugs [20]. During follow-up, the differences were much smaller. Our study found emotional function was worse after transplantation than before $(\mathrm{p}=0.000)$; it was elevated 3 years after transplantation $(\mathrm{p}=0.000)$ but still different to healthy controls after 5 years $(\mathrm{p}=0.011)$. Cancer patients are always under considerable mental stress, feeling worried and anxious. However, during ASCT and HDCT, patients suffered even more tension, worry, and loneliness. With time, self-confidence improved and mental stress was relieved gradually. Many patients returned to being calm and relaxed but still required others to pay attention to them taking care of their body and mind.

Besides physical and mental health, the cancer patients faced somewhat serious social and family problems [21]. Because of fears regarding their disease and economic pressure, patients usually experienced tension in the family, role function subsidence, and social function defects, and started avoiding responsibility. Someone needed more than 5 years to recover [22]. Other studies [23] indicated that most patients after transplant were satisfied with their function recovery. In this study - except for cognitive function which was damaged after transplantation and then got gradually better - role, social function, and global health of the patients were not significantly different before and after ASCT, and were similar between patients 5 years after transplant and healthy controls. We conclude that society had noted the importance of a wholesome approach to recovery of cancer patients, so 
Table 4. Correlation analysis between effect factors and the quality of life (QOL) scores.

\begin{tabular}{|c|c|c|c|c|c|c|c|c|c|}
\hline \multirow[t]{2}{*}{ Items } & \multicolumn{9}{|c|}{ Correlation, $r$ value ( $p$ value) } \\
\hline & age & $\begin{array}{l}\text { menopausal } \\
\text { status }\end{array}$ & $\begin{array}{l}\text { tumor } \\
\text { type }\end{array}$ & $\begin{array}{l}\text { tumor } \\
\text { size }\end{array}$ & stage & $\begin{array}{l}\text { ECOG } \\
\text { score }\end{array}$ & $\begin{array}{l}\text { education } \\
\text { level }\end{array}$ & $\begin{array}{l}\text { social } \\
\text { status }\end{array}$ & income \\
\hline Physical function & $\begin{array}{l}-0.385 \\
(0.002)\end{array}$ & $\begin{array}{l}-0.192 \\
(0.138)\end{array}$ & $\begin{array}{l}0.243 \\
(0.059)\end{array}$ & $\begin{array}{l}-0.333 \\
(0.009)\end{array}$ & $\begin{array}{l}-0.474 \\
(0.000)\end{array}$ & $\begin{array}{l}-0.451 \\
(0.000)\end{array}$ & $\begin{array}{l}0.011 \\
(0.935)\end{array}$ & $\begin{array}{l}0.024 \\
(0.855)\end{array}$ & $\begin{array}{l}0.263 \\
(0.040)\end{array}$ \\
\hline Role function & $\begin{array}{l}0.066 \\
(0.615)\end{array}$ & $\begin{array}{l}0.032 \\
(0.809)\end{array}$ & $\begin{array}{l}-0.163 \\
(0.208)\end{array}$ & $\begin{array}{l}-0.213 \\
(0.100)\end{array}$ & $\begin{array}{l}-0.137 \\
(0.294)\end{array}$ & $\begin{array}{l}-0.025 \\
(0.850)\end{array}$ & $\begin{array}{l}-0.231 \\
(0.073)\end{array}$ & $\begin{array}{l}0.172 \\
(0.185)\end{array}$ & $\begin{array}{l}0.037 \\
(0.778)\end{array}$ \\
\hline Emotional function & $\begin{array}{l}0.101 \\
(0.437)\end{array}$ & $\begin{array}{l}0.330 \\
(0.009)\end{array}$ & $\begin{array}{l}0.092 \\
(0.478)\end{array}$ & $\begin{array}{l}0.012 \\
(0.924)\end{array}$ & $\begin{array}{l}-0.086 \\
(0.511)\end{array}$ & $\begin{array}{l}0.092 \\
(0.482)\end{array}$ & $\begin{array}{l}-0.390 \\
(0.002)\end{array}$ & $\begin{array}{l}0.371 \\
(0.003)\end{array}$ & $\begin{array}{l}0.042 \\
(0.746)\end{array}$ \\
\hline Cognitive function & $\begin{array}{l}0.183 \\
(0.158)\end{array}$ & $\begin{array}{l}0.047 \\
(0.720)\end{array}$ & $\begin{array}{l}-0.044 \\
(0.737)\end{array}$ & $\begin{array}{l}0.080 \\
(0.538)\end{array}$ & $\begin{array}{l}0.022 \\
(0.867)\end{array}$ & $\begin{array}{l}0.110 \\
(0.400)\end{array}$ & $\begin{array}{l}0.059 \\
(0.652)\end{array}$ & $\begin{array}{l}-0.037 \\
(0.780)\end{array}$ & $\begin{array}{l}-0.275 \\
(0.032)\end{array}$ \\
\hline Social function & $\begin{array}{l}-0.041 \\
(0.753)\end{array}$ & $\begin{array}{l}0.193 \\
(0.135)\end{array}$ & $\begin{array}{l}-0.079 \\
(0.547)\end{array}$ & $\begin{array}{l}-0.025 \\
(0.846)\end{array}$ & $\begin{array}{l}-0.065 \\
(0.617)\end{array}$ & $\begin{array}{l}-0.191 \\
(0.139)\end{array}$ & $\begin{array}{l}0.027 \\
(0.838)\end{array}$ & $\begin{array}{l}0.075 \\
(0.567)\end{array}$ & $\begin{array}{l}-0.004 \\
(0.973)\end{array}$ \\
\hline $\begin{array}{c}\text { Global health/ } \\
\text { QOL scale }\end{array}$ & $\begin{array}{l}-0.355 \\
(0.005)\end{array}$ & $\begin{array}{l}-0.144 \\
(0.270)\end{array}$ & $\begin{array}{l}-0.072 \\
(0.579)\end{array}$ & $\begin{array}{l}-0.035 \\
(0.791)\end{array}$ & $\begin{array}{l}-0.089 \\
(0.496)\end{array}$ & $\begin{array}{l}-0.117 \\
(0.367)\end{array}$ & $\begin{array}{l}0.000 \\
(0.998)\end{array}$ & $\begin{array}{l}0.269 \\
(0.036)\end{array}$ & $\begin{array}{l}0.013 \\
(0.919)\end{array}$ \\
\hline Fatigue & $\begin{array}{l}0.330 \\
(0.009)\end{array}$ & $\begin{array}{l}0.280 \\
(0.029)\end{array}$ & $\begin{array}{l}0.053 \\
(0.684)\end{array}$ & $\begin{array}{l}0.089 \\
(0.494)\end{array}$ & $\begin{array}{l}0.030 \\
(0.819)\end{array}$ & $\begin{array}{l}0.099 \\
(0.448)\end{array}$ & $\begin{array}{l}-0.174 \\
(0.180)\end{array}$ & $\begin{array}{l}0.170 \\
(0.191)\end{array}$ & $\begin{array}{l}0.082 \\
(0.530)\end{array}$ \\
\hline Nausea/vomiting & $\begin{array}{l}-0.046 \\
(0.726)\end{array}$ & $\begin{array}{l}0.035 \\
(0.789)\end{array}$ & $\begin{array}{l}0.147 \\
(0.257)\end{array}$ & $\begin{array}{l}0.043 \\
(0.745)\end{array}$ & $\begin{array}{l}0.044 \\
(0.734)\end{array}$ & $\begin{array}{l}-0.001 \\
(0.993)\end{array}$ & $\begin{array}{l}-0.092 \\
(0.479)\end{array}$ & $\begin{array}{l}0.044 \\
(0.739)\end{array}$ & $\begin{array}{l}-0.071 \\
(0.586)\end{array}$ \\
\hline Pain & $\begin{array}{l}0.129 \\
(0.320)\end{array}$ & $\begin{array}{l}0.225 \\
(0.081)\end{array}$ & $\begin{array}{l}0.062 \\
(0.635)\end{array}$ & $\begin{array}{l}0.042 \\
(0.746)\end{array}$ & $\begin{array}{l}-0.033 \\
(0.798)\end{array}$ & $\begin{array}{l}0.079 \\
(0.547)\end{array}$ & $\begin{array}{l}-0.035 \\
(0.792)\end{array}$ & $\begin{array}{l}-0.131 \\
(0.315)\end{array}$ & $\begin{array}{l}-0.127 \\
(0.330)\end{array}$ \\
\hline Dyspnea & $\begin{array}{l}-0.002 \\
(0.988)\end{array}$ & $\begin{array}{l}-0.027 \\
(0.836)\end{array}$ & $\begin{array}{l}0.175 \\
(0.178)\end{array}$ & $\begin{array}{l}-0.041 \\
(0.751)\end{array}$ & $\begin{array}{l}-0.111 \\
(0.393)\end{array}$ & $\begin{array}{l}0.063 \\
(0.630)\end{array}$ & $\begin{array}{l}-0.188 \\
(0.147)\end{array}$ & $\begin{array}{l}-0.160 \\
(0.218)\end{array}$ & $\begin{array}{l}0.039 \\
(0.766)\end{array}$ \\
\hline Sleep disturbance & $\begin{array}{l}0.281 \\
(0.028)\end{array}$ & $\begin{array}{l}0.101 \\
(0.439)\end{array}$ & $\begin{array}{l}-0.031 \\
(0.810)\end{array}$ & $\begin{array}{l}0.336 \\
(0.008)\end{array}$ & $\begin{array}{l}0.473 \\
(0.000)\end{array}$ & $\begin{array}{l}0.318 \\
(0.012)\end{array}$ & $\begin{array}{l}0.085 \\
(0.516)\end{array}$ & $\begin{array}{l}-0.056 \\
(0.666)\end{array}$ & $\begin{array}{l}-0.175 \\
(0.176)\end{array}$ \\
\hline Loss of appetite & $\begin{array}{l}0.065 \\
(0.619)\end{array}$ & $\begin{array}{l}0.009 \\
(0.947)\end{array}$ & $\begin{array}{l}0.016 \\
(0.902)\end{array}$ & $\begin{array}{l}0.004 \\
(0.975)\end{array}$ & $\begin{array}{l}-0.021 \\
(0.871)\end{array}$ & $\begin{array}{l}-0.177 \\
(0.172)\end{array}$ & $\begin{array}{l}-0.169 \\
(0.194)\end{array}$ & $\begin{array}{l}-0.025 \\
(0.847)\end{array}$ & $\begin{array}{l}0.236 \\
(0.068)\end{array}$ \\
\hline Constipation & $\begin{array}{l}0.123 \\
(0.346)\end{array}$ & $\begin{array}{l}0.199 \\
(0.124)\end{array}$ & $\begin{array}{l}-0.172 \\
(0.184)\end{array}$ & $\begin{array}{l}-0.040 \\
(0.757)\end{array}$ & $\begin{array}{l}-0.069 \\
(0.597)\end{array}$ & $\begin{array}{l}0.054 \\
(0.680)\end{array}$ & $\begin{array}{l}-0.002 \\
(0.986)\end{array}$ & $\begin{array}{l}-0.306 \\
(0.016)\end{array}$ & $\begin{array}{l}-0.118 \\
(0.365)\end{array}$ \\
\hline Diarrhea & $\begin{array}{l}0.062 \\
(0.635)\end{array}$ & $\begin{array}{l}0.348 \\
(0.006)\end{array}$ & $\begin{array}{l}-0.151 \\
(0.246)\end{array}$ & $\begin{array}{l}-0.097 \\
(0.544)\end{array}$ & $\begin{array}{l}-0.028 \\
(0.833)\end{array}$ & $\begin{array}{l}-0.027 \\
(0.833)\end{array}$ & $\begin{array}{l}-0.098 \\
(0.450)\end{array}$ & $\begin{array}{l}-0.007 \\
(0.958)\end{array}$ & $\begin{array}{l}0.041 \\
(0.754)\end{array}$ \\
\hline Financial impact & $\begin{array}{c}-0.146 \\
(0.262)\end{array}$ & $\begin{array}{l}0.073 \\
(0.573)\end{array}$ & $\begin{array}{c}-0.096 \\
(0.464)\end{array}$ & $\begin{array}{l}0.193 \\
(0.135)\end{array}$ & $\begin{array}{l}0.284 \\
(0.026)\end{array}$ & $\begin{array}{l}0.230 \\
(0.074)\end{array}$ & $\begin{array}{l}0.241 \\
(0.061)\end{array}$ & $\begin{array}{c}-0.107 \\
(0.410)\end{array}$ & $\begin{array}{c}-0.582 \\
(0.000)\end{array}$ \\
\hline
\end{tabular}

$\mathrm{p}<0.05$ means the two groups are significantly correlated.

these patients were respected, supported, and understood well by society. Accordingly, social communication and duties of these patients after ASCT were not notably impaired.

\section{Symptom and Six Single Items}

Fatigue was very obvious after HSCT. Most patients felt fatigue, and in $67.5 \%$ it was moderate or high. Some studies [24] show that patients in a short period after transplantation had very obvious symptoms of fatigue which continued even 5 years after transplantation. We call this cancer-related fatigue which can be effectively improved by using psychological adjustment and behavior therapy [25]. Other ways to relieve fatigue include easing tension, nutritional therapy, saving energy, engaging in light manual work. Medical workers should be aware of cancer-related fatigue and investigate the causes in order to take effective interventions to help patients to alleviate fatigue.

This study showed that loss of appetite and diarrhea were obvious after transplantation but improved gradually with no significant difference to healthy controls 5 years later. Therefore, patients should observe a reasonable diet during the transplantation process, and not drink or eat too much at once and avoid eating greasy or sweet foods. A reasonable diet can help patients to recover well.

Pain is one of the most important problems faced by cancer patients, which usually exists through the whole course of treatment and recovery and has a serious impact on QOL. This study also reflected this problem. Pain constantly impaired the QOL of the cancer patients before and after transplantation, and was not entirely resolved even after 5 year. Nowadays, doctors are aware of the importance of relieving pain, and many new methods and drugs have been developed. It is not only very significant to the treatment but also improves QOL.

Economic aspect, before and after transplantation, were significantly different. Economic difficulties would ease 5 years after transplantation but were still more serious than in healthy controls; $79.3 \%$ of patients thought that treatment 
costs caused economic difficulties. Other studies [26] reported economic difficulties were prevalent in long-term survivors after transplantation as well as other forms of cancer or chronic diseases [27]. With the current average standard of living in China, completing the entire treatment course would result in great economic difficulties. Patients who have basic medical insurance would bear a lesser economic burden.

\section{Correlation Analysis}

Helder et al. [28] indicated that in terms of age, gender, and some other factors, there was no difference between bone marrow transplant in childhood and in adulthood. From this test, we analyzed the correlation between the QOL and some effect factors, and concluded that age was negatively correlated with physical functions and global health, and positively correlated with fatigue and sleep disturbance. With increasing age, the patients' physical function and global health become worse, and fatigue and insomnia become more evident. Therefore, in the course of treatment, medical workers should pay particular attention to older patients and as far as possible help them alleviate physical suffering. If necessary, drugs can be used to relieve insomnia, pain, and other symptoms.

Menopausal status has a positive correlation with emotional function, fatigue, and diarrhea. The younger patients seemed to be more sensitive when facing disease. Premenopausal women tended to be easily worried, afraid, and sensitive, and lose interest in everything. They need encouragement to return to work and recover their daily activities. Postmenopausal women suffer from the significant changes to their body, and usually feel fatigue. They should pay attention to resting and do exercises.

Tumor characteristics also had an impact on QOL. From this study, we can conclude that tumor size, stage, and ECOG score were negatively correlated with physical function and positively correlated with sleep disturbance. That is because higher-risk breast cancer patients always have a worse prognosis and suffer more physical and psychological pain and stress. In advanced-stage cancer patients that cannot recover completely, the most important thing is to elevate QOL.

In this analysis, emotional function was negatively correlated with education level. More educated patients look up information about their disease in books, the internet, and other ways, but cannot judge correctly the bulk of information they are reading. As a result, worries and anxieties increased, and they became more nervous and less confident. Medical workers should pay special attention to this patient group, patiently answer their questions, and guide them to get information through the correct channels. Psychological guidance is needed to alleviate and actively treat emotional problems.

Some studies did not find marital status and QOL to be correlated [29] considering that the impact of being married or unmarried, or living alone or with others, was not obvious.
Results showed that marital status was positively correlated with emotional function. Those married or living with family could bear physical pain and psychological pressure better than those unmarried, widowed, or living alone. The family's understanding and encouragement would give the patient hope for survival, while being without a family's support can evoke feelings of loneliness and disappointment. Therefore, families should be offered guidance how to lift a patient's spirit and increase his/her confidence which has a significant impact on treatment completion and rehabilitation.

Economic circumstances is an important effect factor of QOL. This study shows that physical function was positively correlated with income level, and negatively correlated with the extent of economic difficulties. Therefore, with living standards and the medical insurance system improving, there will be more patients getting benefit, and QOL will be better. Meanwhile, we should pay more attention to patients without health insurance or with heavy economic burden, and try to keep medical expenses low for them and alleviate economic pressure.

\section{Conclusion}

With the medical approach having changed from a purely biomedical model to a social-psychological-medical model, evaluating QOL allows medical workers to fully understand a patient's state of health, and aid the estimation and selection of clinical treatment methods. This is very significant for assessment of curative efficacy and prognosis, cost-benefit analysis of health resources, health care guidance, health education, or rehabilitation treatment. The European Bone Marrow Transplantation Collaborative Group and other centers [30] recommend that medical workers should gain a clear understanding of the patients' psychological problems after transplantation. It is important to test patients' QOL in the postoperative recovery period, after 6 months, after 1 year, and in each year of follow-up. There are some limitations to this study, for example, longer follow-up and more patients are needed. Also, the correlation between survival rate and QOL could be explored further.

\section{Acknowledgement}

We greatly appreciate the sincere interest and valuable help received from Xingguang Yang. We give special thanks to Jun Ma for data management. We also thank the clinical staff at Tianjin Medical University Cancer Institute and Hospital for follow-up of patients and other patientrelated work.

\section{Conflict of Interest}

The authors did not provide a conflict of interest statement. 


\section{References}

1 Partridge AH, Bunnell CA, Winer EP: Quality of life issues among women undergoing high-dose chemotherapy for breast cancer. Breast Dis 2001; 14:41-50.

2 Slovacek L, Slovackova B, Jebavy L: Global quality of life in patients who have undergone the hematopoietic stem cell transplantation: finding from transversal and retrospective study. Exp Oncol 2005; 27:238-42.

$\checkmark 3$ Peters WP, Dansey RD, Klein JL, Baynes RD: High-dose chemotherapy and peripheral blood progenitor cell transplantation in the treatment of breast cancer. Oncologist 2000;5:1-13.

4 Armitage JO: High-dose chemotherapy and autologous hematopoietic stem cell transplantation: the lymphoma experience and its potential relevance to solid tumors. Oncology 2000;58:198-206.

$\checkmark 5$ Syrjala KL, Langer SL, Abrams JR, et al.: Recovery and long term function after hematopoietic cell transplantation for leukemia or lymphoma. JAMA 2004;291:2335-43.

6 McQuellon RP, Russell GB, Cella DF, et al. Quality of life measurement in bone marrow transplantation: development of the Functional Assessment of Cancer Therapy-Bone Marrow Transplant (FACT-BMT) scale. Bone Marrow Transplant 1997;19:357-68.

7 Amato JJ, Williams M, Greenberg C: Psychological support to an autologous bone marrow transplan unit in a community hospital: a pilot experience. Psycho-Oncol 1998;7:121-5.

8 Watson M, Buck G, Wheatley K, et al.: Adverse impact of bone marrow transplantation on quality of life in acute myeloid leukaemia patients; analysis of the UK Medical Research Council AML 10 Trial. Eur J Cancer 2004;40:971-8.

9 Larsen J, Gardulf A, Nordstrom G, et al.: Healthrelated quality of life in women with breast cancer undergoing autologous stem cell transplantation. Cancer Nurs 1996;19:368-75.

10 Huober J, Schneeweiss A, Hohaus S, et al.: Tandem and triple high-dose chemotherapy with autologous stem cell rescue in metastatic breast cancer. J Cancer Res Clin Oncol 1998;124:690-4.

11 Child JA, Morgan GJ, Davies FE, et al.: High-dose chemotherapy with hematopoietic stem-cell rescue for multiple myeloma. New Engl J Med 2003; 348:1875-83.
12 Syrjala KL, Dikmen S, Langer SL, Roth-Roemer S, Abrams JR: Neuropsychologic changes from before transplantation to 1 year in patients receiving myeloablative allogeneic hematopoietic cell transplant. Blood 2004;104:3386-92.

13 Diez-Campelo M, Perez-Simon JA, Gonzalez-Porras JR: Quality of life assessment in patients undergoing reduced intensity conditioning allogeneic as compared to autologous transplantation: results of a prospective study. Bone Marrow Transplant 2004; 34:729-38

14 Andrykowski MA, Bishop MM, Hahn EA, et al.: Long-term health-related quality of life, growth, and spiritual well-being after hematopoietic stemcell transplantation. J Clin Oncol 2005;23:599-608.

15 Aaronson NK, Ahmedzai S, Bergman B: The European Organization for Research and Treatment of Cancer QLQ-C30: a quality of life instrument for use in international clinical trials in oncology.J Natl Cancer Inst 1993;85:365-76.

16 Sprangers MA, Cull A, Bjordal K, Groenvold M, Aaronson NK: The European Organization for Research and Treatment of Cancer. Approach to quality of life assessment: guidelines for developing questionnaire modules. EORTC Study Group on Quality of Life. Qual Life Res 1993;2:287-95.

17 Andrykowski MA, Bishop MM, Hahn EA, Cella DF, Beaumont JL, Brady MJ, Horowitz MM, Sobocinski KA, Rizzo JD, Wingard JR: Long-term health-related quality of life, growth, and spiritual well-being after hematopoietic stem cell transplantation. J Clin Oncol 2005;23:599-608.

18 Prieto JM, Atala J, Blanch J: Patient-rated emotional and physical functioning among hematologic cancer patients during hospitalization for stem-cell transplantation. Bone Marrow Transplant 2005;35: 307-14.

19 Hjermstad MJ, Evenson SA, Kvaloy SO, et al.: Health-related quality of life 1 year after allogeneic or autologous stem-cell transplantation: a prospective study. J Clin Oncol 1999;17:706-18.

20 Sasaki T, Akaho R, Sakamaki H: Mental disturbances during isolation in bone marrow transplant patients with leukemia. Bone Marrow Transplant 2000;25:315-8.

21 Heejung Yoo, Kyoohyung Lee, Jehwan Lee, et al.: Korean translation and validity of FACT-BMT version 4 and the quality of life in allogeneic bone marrow transplantation patients. Qual Life Res 2006;15:559-64.
22 Kopp M, Holzner B, Meraner V, et al.: Quality of life in adult hematopoietic cell transplant patients at least 5 yr after treatment: a comparison with healthy controls. Eur J Haematol 2005;74:304-8.

23 Edman L, Larsen J, Hägglund H, Gardulf A: Health-related quality of life, symptom distress and sense of coherence in adult survivors of allogenic stem-cell transplantation. Eur Cancer Care 2001; 10:124-30.

24 Danaher EH, Ferrans C, Verlen E, Ravandi F, van Besien K, Gelms J, Dieterle N: Fatigue and physical activity in patients undergoing hematopoietic stem cell transplant. Oncol Nurs Forum 2006;33:614-24.

25 Hjermstad MJ, Knobel H, Brinch L, et al.: A prospective study of health-related quality of life, fatigue, anxiety and depression 3-5 years after stem cell transplantation. Bone Marrow Transplant 2004; 34:257-66.

26 Hayden PJ, Keogh F, Ni Conghaile M, et al.: A single-centre assessment of long-term quality-of-life status after sibling allogeneic stem cell transplantation for chronic myeloid leukaemia in first chronic phase. Bone Marrow Transplant 2004;34:545-56.

27 Cook R: Economic and clinical impact of multiple myeloma to managed care. J Manag Care Pharm 2008;14(suppl):19-25.

28 Helder DI, Baker B, de Heer P: Quality of life in adults following bone marrow transplantation during childhood. Bone Marrow Transplant 2004;33: 329-36.

29 Andersson I, Hjermstad M, Stockelberg D: Health related quality of life in stem cell transplantation: clinical and psychometric validation of the questionnaire module, High Dose Chemotherapy (HDC-19). Acta Oncologica 2008;47:275-85.

30 Rizo JD, Wingard JR, Tichelli A: Recommended screening and preventive practices for long-term survivors after hematopoietic cell transplantation :joint recommendations of the European Group for Blood and Marrow Transplantation, Center for International Blood and Marrow Transplant Research, and the American Society for Blood and Marrow Transplantation(EBMT/CIBMTR/ ASBMT). Bone Marrow Transplant 2006;37:249-61. 